\title{
Integration Practices for the Technological Innovation of Products: Case Studies at Two Large Technological Companies
}

\author{
Daniel Jugend', Sérgio Luis da Silva², Luís Fernando Magnanini Almeida ${ }^{3}$, José Alcides Gobbo Junior ${ }^{4}$
}

\begin{abstract}
Studies on innovation and technology management have emphasized the importance of integration between the research and development (R\&D) department and others involved with the product development process (PDP) as a relevant practice for the good performance of technological innovation of product activities. This study addresses the topic of transfers of technologies to new product projects and also integration practices between the R\&D department and others involved with the PDP. A qualitative study was conducted that was operationalized through two case studies at large high-tech companies: One is Brazilian and the other is a multinational subsidiary in Brazil. Among its main result, this paper represents and analyzes management practices that are favorable to integration in product development projects that demand development and transfer of technologies, such as: participation of R\&D personnel in market activities, the adoption of virtual interaction mechanisms, and the application of methods such as technology roadmaps.
\end{abstract}

Keywords: technological innovation of products; integration; technology-based companies.

Department of Production Engineering - Universidade Estadual Paulista (UNESP). Av. Eng. Luiz Edmundo Carrijo Coube 140I, Bauru - SP - Brazil. Phone: 55 I4 31036I22. E-mail: 'daniel@feb.unesp.br, ${ }^{4}$ gobbo@feb.unesp.br. ${ }^{3}$ Phone: 55 I6 335 I8237. E-mail: magnanini.If@gmail.com

2Department of Information Sciences - Federal University of Sao Carlos (UFSCar). Rod.Washington Luiz, km 235, I3565-905 - São Carlos SP - Brazil. Phone: 5516335 I8374. E-mail: sergiol@ufscar.br 


\section{Introduction}

Technological advances allied with intensified competition, not only on a local but also on a global level, have forced companies to develop more complex products more quickly, with better quality, and at a competitive cost. Although the efficient development of new products is also recognized as providing new opportunities for companies, the risk of developing them and launching them cannot be neglected.

Studies on innovation and technology management have emphasized the importance of integration between the product development process (PDP) and technology development activities, traditionally carried out by the research and development (R\&D) department, as a relevant mechanism for companies to achieve their technological innovation of products objectives (Brettel et al., 20I I; Jugend and Silva, 20I0; Song and Song, 20I0).

A product can be defined as any object designed and produced to meet a particular commercial purpose, and as such, it can incorporate various technologies (Schulz et al., 2000). The development of technologies refers to a special class of project development that aims to produce new tangible elements, such as machines, tools, and systems (Burgelman et al. 200I; Gopalakrishnan and Santoro, 2004). These technologies can then be transferred to product development projects (Green et al., 1996; Magnusson and Johansson, 2008) and generate technological innovations of processes or products. The technological innovation of products depends on work that adds knowledge that belongs to several functions and specialties of a company (multifunctional nature) with the intent of developing and launching a product that has a specific commercial application of new knowledge.

This study defines integration between R\&D and the PDP as the collaborative and interactive work between different departments and specialists at a company with the objective of creating knowledge and/or technological solutions to be transferred to one or more products during the PDP (Calantone and Rubera, 2012; Drejer, 2002; Nobelius, 2004; Olson et al., 200I).

A study published by Product Development \& Management Association (PDMA), which collected information from 416 executives who work in different industrial sectors and who are directly involved with the PDP, demonstrated that good integration management is one of companies' frequently adopted practices that present high levels of performance related to product development (Barczak et al., 2009).

However, some studies indicate that integration between the R\&D department and those involved with the PDP (engineering, manufacturing, and supplies and marketing, for example) is not considered to be a trivial activity (Griffin and Hauser, 1996; Jugend and Silva, 2012; Song and Song, 20I0). Maltz et al. (200I) and Brettel et al. (20II) state that the presence of cultural barriers, difficulties in communication and common understandings, and different department objectives can be underscored as aspects that hinder the integration of different functions involving the PDP and technology development. The challenge of achieving effective collaboration is further increased, not only by physical distance, but also by differences in languages, culture, education, government regulations and time zones.

In relation to the technological innovation of products activities, different from smaller companies, medium and large high-tech companies deserve special attention because they are the ones that have the conditions needed to carry out systematic technological innovation activities in product development, as they normally own the resources needed for such, including: facilities, machines, proper labor, investments in R\&D, and specific competences in project and product engineering. Furthermore, at large companies, those difficulties related to integration in product development tend to manifest themselves in a more intense manner; after all, it is common to find greater functional division at these companies as well as the geographic separation between departments/ functions involved with these development jobs (Eppringer and Chitkara, 2006; Song et al., 2000).

For these reasons, the objective of this paper consists of presenting and comparing the technological innovation process for products and management practices for integration between the R\&D department/function with the other functions involved with the PDP. For such, besides the theoretical review of the theme, a qualitative study was conducted and operationalized through two case studies at large high-tech companies: one is a Brazilian company and the other is a Japanese multinational.

This paper starts with a literature review of the theme, and then, those aspects that refer to the research method employed in the study are handled. After that, the companies that were examined and the results obtained in this study are presented. In conclusion, final remarks are outlined.

\section{Literature Review}

Burgelman et al. (200I) define technology as the results of specific activities by a company that transfers findings, inventions, and the development of new knowledge to its products and processes. DT refers to the process of acquisition and/or development of knowledge so that it can be transferred and used in product projects. Figure I, which Evans and Gausslin (2005) proposed, illustrates the idea of technology development and transfer to a company's products.

ISSN: 07 I8-2724. (http://www.jotmi.org)

Journal of Technology Management \& Innovation (c) Universidad Alberto Hurtado, Facultad de Economía y Negocios. 
Cerra et al. (2010) points out that DT is often associated with technological strategy. Technological strategy can be defined as the orientation of a company's plans, programs, efforts, and actions within the scope of R\&D activities as well as the company's other functions, aimed at strengthening and/or expanding its technological capacity in order to contribute toward achieving the business' objectives.

The R\&D function is indicated in several studies about innovation and technology management as one of the most important and traditional forms found at companies for the development of technologies (Bound and Houston, 2003; Souder et al. 1997).Whitney (2007) points out that the R\&D function has a dual attribution at companies: Research is the development of new ideas to solve a problem or take advantage of an opportunity, and development is the attempt to operationalize those ideas that stem from research activities in order to test, refine, and prepare them for commercial applications.

The generation and mastery of technologies has a more ample scope than does product development because it enters the generation and development of new knowledge to be applied directly or indirectly to a specific product or production process. The technology can serve as an opportunity or a limitation (technological possibilities and restrictions) for the PDP because the possibility for developing a specific product may depend on variables that the technologies determine, such as: the availability of technology, possibility and restrictions for the development of this technology, and possibilities for the transfer of technology to product development programs.

In dealing with the transfer of new technologies to new products, Shulz et al. (2000) and Creveling et al. (2003) recommend ensuring that only flexible, robust, and mature technologies be transferred to new product projects. The logic of these authors consists of seeking to take ad- vantage of the technology developed in different company products and to avoid problems of quality, cost, and programming of times for new product development activities due to immature or uncertain technologies incorporated into the products.

Projects for new products often depend on the development and transference of new technologies. Therefore, these projects require the collaborative and interactive work of various roles and skills (i.e., the need for integration between a company's R\&D and other functions involved with their PDP) - for example, marketing, engineering, supply, production, and logistics. (Calantone and Rubera, 2012; Jugend and Silva, 2010; Nobelius, 2004; Song and Song, 2010).

Interpreting what the authors had addressed regarding the subject of integration between the roles of R\&D and others involved in the PDP (lansiti, 1998; Nobelius, 2004; Park et al., 2009; Song and Song, 20I0), we understood that this integration occurred when interactive and collaborative work occurred between the different roles and skills, with the objective of creating technical knowledge and/or solutions that can be transferred to one or more products during the PDP. For Priest and Sanchez (200I) and Calantone and Rubera (2012), the work of integration is not a simple activity. Johansson et al. (2006) illustrated the complexity of integration by emphasising that the role of technology development needs to jointly operate with those roles that work with the PDP, as they need to provide new ideas, materials, components, and tools for such product development activities.

The work of Griffin and Hauser (1996), Park et al. (2009), and Song and Song (2010) all highlighted the difficulties of enacting integration, mainly as a result of company growth and resulting increases in management complexity. Normally certain roles, such as marketing, engineering and R\&D, become very specialised regarding their different visions and goals. As such, they often act in isolation and with insuffi-

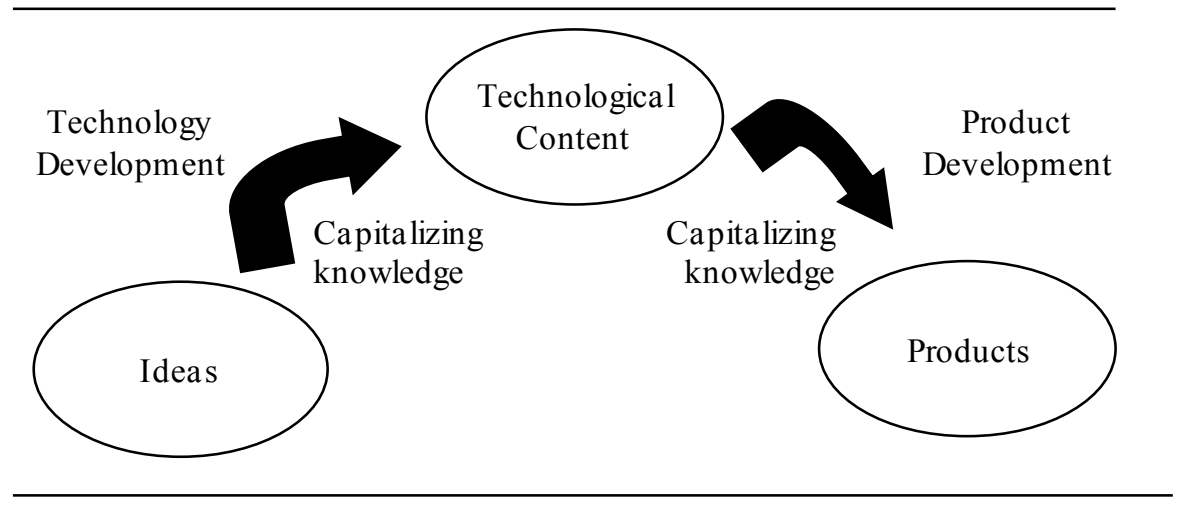

Figure I:Technology Development and Product Development (Source:Adapted from Evans and Gausslin, 2005, p. 32).

ISSN: 07I 8-2724. (http://www.jotmi.org)

Journal of Technology Management \& Innovation (c) Universidad Alberto Hurtado, Facultad de Economía y Negocios. 
cient collaboration, communication, or sharing of knowledge with the other departments. Nevertheless, as Farjoun (2010) noted, successful innovative activities depend a great deal on the systematic and collective participation of various specialist skills and require management mechanisms that encourage the combination and sharing of routines and knowledge between these different specialists.

To overcome the difficulty of such integration, recent revisions have shaped the relevant literature in the area of innovation and technology management that deal with the subject of product technology innovation and integration. To minimise problems resulting from cultural barriers between departments involved in the product production process and related technologies, Maltz et al. (200I), Love and Roper (2009), and Park et al. (2009) proposed the use of cross-functional teams as a good managerial practice to increase the transference of knowledge and to achieve the integration.

Leendres and Wirenga (2002) noted that as a result of faceto-face contacts, a greater degree of collaboration and interaction between the roles occurred when they worked in the same installations. In other words, when referring to physical proximity. As noted by Allen (1977), people are hardly likely to collaborate if they are more than 50 feet apart. Brettel et al. (20II) recognised that it was beneficial for integration that the R\&D and engineering managers participate in the activities of market research and have contacts with clients along with personnel from marketing.

The Technology Roadmap (TRM), which aims to represent, through graphs, the connection between company objectives, product portfolios, and the development of technologies (Phaal et al., 2004; Oliveira et al., 2012), is also recommended, by some studies, as useful for the integration between the PDP and DT studies (Phaal et al., 2004). The reason is that the development of the TRM does project the adoption of management practices that intensify functional integration, such as the formation of cross-functional teams and the applications of methods including quality function deployment, stage-gates, and brainstorming, among others.

\section{Research Method}

With the objective of presenting and comparing the technological innovation process for products and management practices for integration between the R\&D department/ function with the other functions involved with the PDP, it was decided to use the qualitative research approach. The reason is that although the research variables are hard to measure, it became necessary to understand the opinion of people concerning these variables and, thus, following Bryman's (2006) recommendations, the presence of a field researcher was necessary.
The case study method was used as the research procedure, which, according to Yin (2005), is fitting when searching for a greater understanding of the researched, contemporary facts. Furthermore, according to Yin (2005), the case study permits an intense analysis of a relatively small number of situations and, at times, the number of cases drops to one because emphasis is given to an ample understanding of the phenomenon.

The choice of companies was intentional. In a preliminary contact with the professionals, it was observed that they have the requirements that are considered indispensable for participating in this study, which are: presence of a structured R\&D department and systematic development activities as well as the transfer of technologies to its new product programs. Furthermore, with the objective of researching large companies, the Brazilian Institute of Geography and Statistics (IBGE) classification was used. According to this institution, large industrial companies are those that have more than 500 employees.

In field research, semi-structured interviews were conducted (a research script was followed that used open and closed questions). Two companies were visited. Their directors and representatives of the R\&D, marketing, engineering, and production departments were interviewed.

\section{Presentation and Analysis of Results}

The empirical results obtained through case studies are presented and analyzed here. Topic 4 .I provides a brief characterization of the researched companies. The following topics present and analyze the transfer of technology to the PDP at the two companies and, also, their main management practices adopted for conducting the integration in product development works that require technological innovations.

\section{Characterization of the Companies}

\section{Company A}

The company is a Japanese multinational that was present in 31 countries. In Brazil, it mainly operated in the optical and industrial automation segments. Its head offices are located in the city of Tokyo, Japan. It has R\&D centers at its head offices and in the United States of America (USA) and Singapore.

It has had operations in Brazil since 1973. Currently, at this unit, it has 370 employees distributed throughout its factory located in the city of São Paulo and in an office that has the following functions: engineering, quality, and marketing, located in São Paulo. Fifty of these employees are allocated to new product development activities, inserted in the engi- 
neering function. The Brazilian unit mainly serves the chemical and petrochemical sectors and, on a smaller scale, the avionics sector. Besides supplying the entire country, the unit installed in the country serves the South American market, especially Argentina, Colombia, Chile, and Peru. Considering the past five years, the Brazilian unit together with the head office developed four platform products that gave origin to several derivative products, many of which developed at the Brazilian unit.

\section{Company B}

Company B operates in the industrial automation segment. It comprises 12 units located in São Paulo state and a production unit in the USA. It has nearly 900 employees, I 40 of which are allocated to R\&D and engineering activities.

It began its activities with the objective of providing services and providing industrial automation products for the sugar and alcohol sectors, which mainly occurred by virtue of the industries' needs in the region where the company is located. At present, besides the sugar and alcohol sectors, the oil and gas and mining sectors are also main clients. Nearly $30 \%$ of sales are to the foreign market. The company only develops products in catalog form. Almost 10 new products are developed annually (between platforms and derivatives). The main product platforms it commercializes are the programmable logic controllers (PLCs) and pressure, density, and temperature transmitters. The company destines nearly $10 \%$ of its revenues to innovative activities, and it has registered 27 patents.

Considering its product portfolio, the company mainly works on developing precision mechanics technologies, software, and electronics, which are transferred to its products (PLC portfolio and pressure, density, and temperature transmitters).

\section{Transfer of Technologies to the Product Development Process}

\section{Company A}

Company A formally separates product and technology development. It has three R\&D centers located in Japan, the USA, and Singapore, which work specifically with the objective of researching and developing new technologies.

The company's branches have the autonomy to conduct product and technology development that meets its local needs and that does not demand great investments. However, the more complex development projects that involve more resources (financial, structure, and personnel) should be sent for analysis and deliberation by the head office.
Considering the products that the Brazilian branch offers, most of the development of technology needs occurs with electronic technologies, optical technologies and, on a smaller scale, telemetry technology. These technologies are transferred to the product portfolio that the company develops and produces (pressure instrumentation equipment, PLCs, and digital distributed control systems, for example).

Every three years, the company's strategic plan is elaborated at the head office, and its results are reviewed every semester. Information resulting from strategic planning and the respective reviews (these results include: products and technologies to be developed) are sent to the branches, and they guide the activities of their diverse functions (including engineering, marketing, and R\&D).

The moments of strategic planning are determining periods for deliberating on products and technologies to be developed. During these periods, the development technologies that are without any immediate commercial application are decided, as are the needs for product development (normally: platforms and radically new ones) and, consequently, the needs for developing technologies to be transferred to these products. A criterion normally used in relation to DT is the potential the technology will have to be transferred to several products (current and/or future portfolio), that is, its degree of flexibility and maturity. This practice was illustrated based on the following example:

The company's R\&D in Tokyo has been working on the development of a wireless technology for more than a year (permits connecting different points without the need for wires). Through definitions presented by the technology roadmap that has been developed and implemented, the company believes that in five years, this will be the predominant technology in industrial instrumentation. Thus, the company's roadmaps (maps of products and technologies to be developed) have already sent and directed their R\&D centers to develop this technology as per the deadlines that the roadmaps stipulated. After making this technology mature, the company intends to adapt and to transfer it to its various instrumentation equipment and thus offer its clients automation products that do not need the physical presence of cables, offering gains in flexibility.

Before the transfer of new technologies to products, the for$\mathrm{mal}$ and systematic procedure is to test the various configurations of the technology developed, to build prototypes of this technology, and to submit these prototypes to different conditions of stress. These activities aim to analyze whether the technology complies with the desired requirements and whether they are robust enough to be transferred to the product portfolio. Figure 2 illustrates this situation. 


\section{Company B}

The company uses three mechanisms for decision-making about the products and technologies to be developed: strategic planning, board meetings, and identification of immediate needs for development.

Strategic planning is associated with the planning of products and technologies for a period of five years. The discussions and decisions made in strategic planning are strongly influenced by results that stem from market research. The president and company directors participate in the strategic planning activity.

Board meetings and the identification of immediate needs for development reflect the portfolio review activities (short-term). Area directors meet systematically every two months with the purpose of reviewing and deliberating on the immediate needs of new projects (DP and needs for developing and transferring technologies) and also the possible discontinuity of products.

The company does not separate the product and technology development. No R\&D function is dedicated exclusively to the DT task while another is dedicated to engineering, being responsible for product project activities, process project activities, and preparation for production. A function called R\&D, as per the diagnosed needs, develops products as well as technologies. In the evaluation of those interviewed, by integrating these activities in the same function, the company obtains greater agility in product development tasks that depend on the development and transfer of technologies. This provides them with a competitive advantage in the face of their main competitors (normally represent- ed by sector multinationals) that generally are slower in development activities.

Taking into account the main families of products produced and commercialized, the company predominantly works with the development of precision mechanics technologies, software, and electronics, which are transferred to its product portfolio. A criterion systematically observed in terms of DT is its degree of flexibility, that is, the potential to be transferred to diverse products (current and/or future portfolio). The company is currently developing new microprocessor solutions. After making this technology mature, the company intends to transfer it to its field equipment which, by virtue of this new technological solution, will offer additional functions.

Before the transfer of technologies developed to products, the formal and systematic procedure is to test the various configurations of the technology developed, to build prototypes of this technology, and to submit these prototypes to different conditions of stress. Such activities aim to analyze whether the technology meets the desired requirements and whether they are robust and mature enough to be transferred to the company's product portfolio.

\section{Practices for Integration between the R\&D Depart- ment and the Product Development Process}

\section{Company A}

The president of the Brazilian unit participates actively in strategic planning activities and reviews at company headquarters. $\mathrm{He}$ is responsible for presenting results and elaborating on action plans together with the directors and

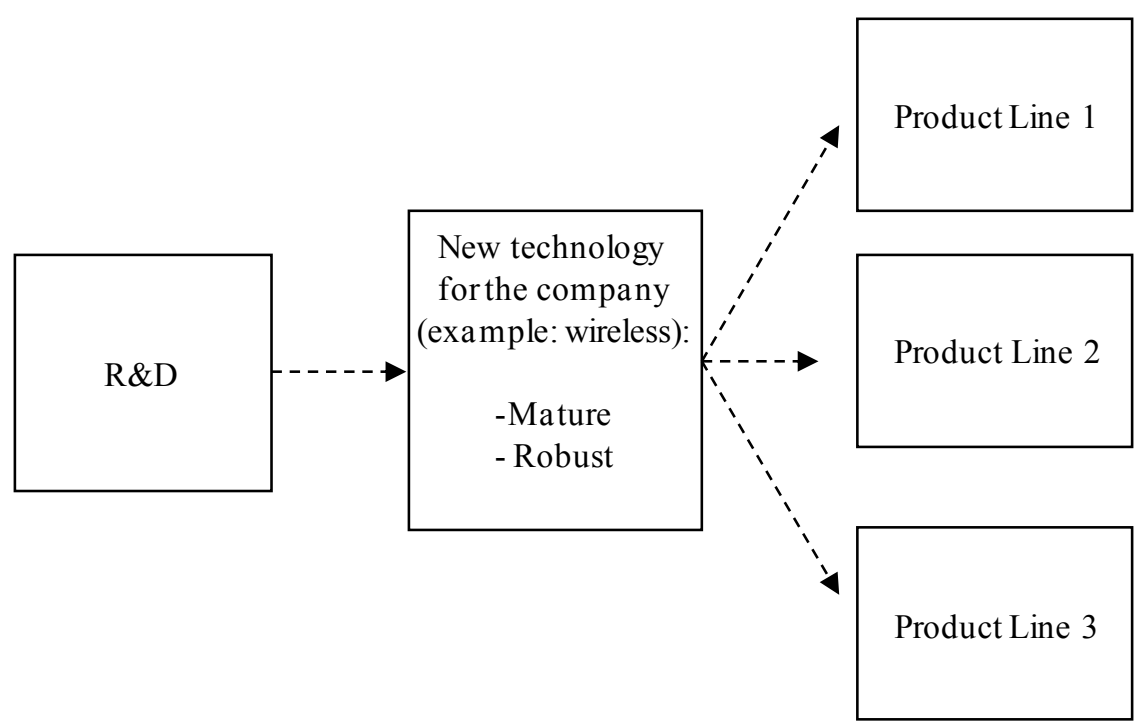

Figure 2:Technology transfer to the company's products.

ISSN: 07I 8-2724. (http://www.jotmi.org)

Journal of Technology Management \& Innovation (c) Universidad Alberto Hurtado, Facultad de Economía y Negocios. 
managers at the branches in Brazil and South America. This practice facilitates the sharing of knowledge and deployment of strategic plans defined by top management to the other branches.

With the purpose of identifying the needs of closer clients and making the customizations needed for their products, the branches should continuously monitor the specific needs of the market in which they operate. In this sense, the Brazilian unit strives to meet the needs of industries installed in South America in terms of industrial automation equipment. In order to identity the needs of these clients, the Brazilian unit uses traditional market survey activities conducted through the marketing function. With the intent of receiving information directly from the market, engineering representatives were observed to collaborate with marketing personnel in activities such as contacting clients and participating in sector trade shows.

The collocation at the Brazilian branch occurs between the marketing and engineering functions. The production function, in turn, is located at the unit's factory in another installation (with the unit's factory). According to those interviewed, this practice facilitates face-to-face contact between marketing and engineering representatives, which favors interaction and consequently improves the sharing of knowledge between these technical and managerial areas involved in new product projects.

However, in product projects that demand technological innovations, collocation is a factor that inhibits integration. That is the reason why the R\&D centers are geographically located distant from the branches (in other countries). Furthermore, the company is able to harness local markets while using expertise available world-wide. The company tries to minimize this geographic distance and increase the integration among marketing, engineering, and production functions at each branch with R\&D centers (located in Japan, the USA and Singapore), through the adoption of virtual tools such as the Internet and Intranet. This means that R\&D company employees are working together with more people than ever before. Furthermore, aimed at improving integration in technology and product development, marketing, engineering, and production managers and coordinators from the Brazilian unit frequently visit the head offices in Japan and the company's other R\&D centers.

The formation of cross-functional teams with representatives from the engineering, production, and marketing functions is a practice institutionalized by the Brazilian branch for new product projects. Marketing personnel tend to have more intense involvement in the predevelopment phase, when the company needs detailed information concerning client needs; during the development phase, the function is temporarily removed from the project because the technical development work becomes the responsibility of engineering and production. It is worth noting that in projects that demand technological innovations, R\&D representatives are inserted in these teams (during the predevelopment, development, and post development phases). In this case, interaction and collaboration occur through mechanisms of virtual tools and onsite visits, as already mentioned in the above paragraphs.

\section{Company B}

At this company, the marketing director and main managers and coordinators are people who have already worked in R\&D (the department that Company B uses to carry out typical engineering and R\&D attributions). This provides for greater alignment of visions between these two functions (technical and managerial for development work) and also strengthens collaboration between them, as there has already been prior work experience among the members who work in the development and marketing functions. Furthermore, the company understands that because they know the technical attributes of the product and technology, marketing personnel is sufficiently trained to understand the needs of clients and transmit this information in a satisfactory manner to R\&D.

Cross-functional teams are formed in every product development project that contains technological innovations. These teams have representatives from R\&D, production, supplies, and marketing. However, it is not unusual for failures to occur in these projections or operational problems during the execution of such projects. When this occurs, a new team is formed, called a "workforce," led by an area director, to try to fulfill the development activity within the allotted timeframe.

However, it was observed that different from the literature's recommendation (Maltz et al., 200I), it is an exclusive attribution for marketing and employees who work "in the field" (installation and technical assistance) to capture information about client needs, that is, the company does not use representatives of the functions that work at tasks related to defining product and process projects; and, identification, development, and mastery of new technologies, to be carried out jointly with marketing activities related to contacting clients and market surveys.

The company indicated that physical distance is an inhibiting element for integration between marketing and R\&D departments for technological innovation of product activities. At this company, marketing is installed in a building far from R\&D, which hampers interaction between the two. With the objective of minimizing this problem, the company 
has already initiated construction of an installation that joins these two functions in a same building.

With regard to the technology roadmap method, the company signaled its implementation as a future tendency in its efforts involving the technological innovation of products. Although they still do not adopt this method in a formal manner, it is known, and its managers show the likelihood of joining forces to initiate its implementation in future projects for the development of products and technology.

The company also underscored that as its technology development projects achieve new results, the respective leaders call meetings with managers of other projects that are in progress. The purpose of these meetings consists of sharing knowledge developed and acquired in these projects with other functions and verifying the immediate possibilities of applying the technology being developed to other new product projects. This practice tends to benefit integration because besides generating gains from the analysis of possibilities for applying the technology developed to other new product projects, it also intensifies the sharing of knowledge acquired from DT works by the R\&D department with other departments at the company.

\section{Analysis of Results}

Because Company A has R\&D activities for technologies to be developed for future times (often only with the intention to strengthen its technological capacity and, without the immediate concern, to transfer it to new product and/or process projects) and it uses its R\&D centers to establish the development of these technologies, it is possible to affirm that in a manner coherent with the proposals by Cerra et al. (20I0), the company is concerned about outlining technological strategies. The decisions about the development of platform or radically new products and technologies are made by top management at the company headquarters. TRM assists the decision process for the development of products and technologies and also the promotion and orientation of development works to be attributed to the company's R\&D centers and units.

Differently, Company B does not have strategies that orient plans, programs, and efforts with the intent of strengthening its future technological competences, without an immediate and well-identified commercial objective in the form of a product or process. The development of technologies at this company is seen as a specific phase of the PDP; that of developing knowledge seen as necessary and applying it to a product and/or process for a specific and already welldefined production process.

The different sizes, organizational structure, availability of resources (human, financial, material, and property) and business objectives explain these different strategies related to the development of technologies at the two companies. In this sense, it is worth noting that Company A is a technology-based multinational present in $3 \mathrm{I}$ countries and has R\&D centers with the exclusive attribution of working in DT. Company B, in turn, although also a large company, operates mainly in Brazil and integrates the typical engineering and $R \& D$ areas in the same function.

When deciding on technologies to be developed, the two companies expressed concern in selecting those considered flexible; that is, those with potential to be transferred to a broad range of already-existing products or products yet to be developed. This was illustrated by Company A, through the example currently in effect, regarding the development of wireless technology, and, by Company B, from its efforts to develop new microprocessor technologies. This practice adopted by the two companies converges with the recommendations of some studies about good development and transfer of technology practices to one or more products in the PDP (Schulz et al., 2000).

With the objective of analyzing whether the technology developed complies with the desired requirements, within its planned lifecycle and, whether it is robust enough to be transferred to its products, both companies construct prototypes and submit them to different stress conditions as procedure. Analyzing this fact, a convergence can be observed between this practice adopted by both companies and the recommendations of developing and transferring technologies to one or more products in the PDP presented by the studies by Shulz et al. (2000) and Creveling et al. (2003), as the companies are actually concerned about simply transferring technologies considered robust to their product projects, which is mainly done through the construction and testing of prototypes.

The geographical distance between the R\&D centers and the units spread about the world hampers the formation of cross-functional teams for developing products with high technological content at Company A. With the intent of minimizing this problem, the company has adopted virtual mechanisms to bring specialists closer together, especially those in marketing, engineering (Brazilian unit), and R\&D. According to those interviewed, which corroborates the recommendations by Eppinger and Chitaka (2006), the insertion of information technology mechanisms has the potential of improving communication standards and transfers of knowledge (especially tacit) in the development of products that depend on the integration of specialists located in different countries. At the company's Brazilian unit, the concern about integrating marketing and engineering specialists in market survey activities that refer to the identification

ISSN: 07 I8-2724. (http://www.jotmi.org)

Journal of Technology Management \& Innovation (c) Universidad Alberto Hurtado, Facultad de Economía y Negocios. 
of local needs of clients and development projects of less technological complexity was observed.

At Company B, the formation of cross-functional teams is an institutionalized practice in projects for developing products with high technological content. Intense integration was observed, especially between the R\&D and marketing functions. The profile of the main marketing managers and coordinators contributes to this. These managers and coordinators have already worked in R\&D and, thus, have the technical knowledge of products and technologies and also recognize the functions limitations and possibilities. Besides that, because the professionals in these two functions have already worked together, the collaboration and interaction among the participating members of these teams tends to be intense, as a given level of social relationship (friendship) already exists between them.

At Company B, different from the recommendation in the proposals by Maltz et al. (200I), the exclusive attribution of market was observed to be the capturing of information about client needs. However, the technical training of its representatives has facilitated the interaction and the sharing of information with specialists from the R\&D in product projects that depend on the development and transfer of technologies.

\section{Final Considerations}

The functional integration demanded by product projects that need the development and transfer of technologies have additional complexities in relation to the product development programs that do not demand technological innovation efforts. After all, these projects also require the integration of R\&D activities and structure (for the identification, development, mastery and transfer of technologies) together with the other functions of a company involved with PDP, such as engineering, production, supplies, and marketing.

This study contributes by presenting a set of favorable management practices for integration to product development projects that demand the development and transfer of technologies. Furthermore, it also underscored differences between development of products and of technologies, often still confused within the business as well as the academic environments.

The application of practices identified in this study can provide subsidies that help to bring different functional specialists closer together, as they often work geographically distant from one another, and they have divergent visions and difficulties in common understanding about the development of products and of technologies. These differences tend to hamper several activities related to the development of technologies and products, such as the translation of client needs into technical requirements for products, and, consequently, jeopardize the performance of product projects that demand technological innovations.

In face of this, this paper, through a literature review and case study, presented concepts about the transfer of technologies to new product projects and integration among development of technologies activities, often represented by the R\&D department, with the others involved with PDP and management practices that favor this integration. The empirical results of this study should, however, be viewed carefully because even considering that the companies studied stand out in terms of technological innovation activities for products, by virtue of the limitation of the method employed, its results cannot be generalized.

Finally, it is expected that the results of this study can add to the theoretical framework about management practices for the development of technologies and of products, contributing to the areas of knowledge in innovation management, technology, and the PDP. Furthermore, this paper is expected to also stimulate future research associated with the theme of integration in new product development. 


\section{References}

ALLEN ,T. (1977). Managing the flow of technology. Boston: MIT Press

BARCZAK, G., Griffin, A., Kahn, K.K. (2009). Perspective: trends and drivers in NPD practices. Journal of Product Innovation Management. 26 (I),. 3-23.

BOND, E. U., Houston, M.B. (2003). Barriers to matching new technologies and market opportunities in established firms, The Journal of Product Innovation Management, 20 (2), I20-135.

BRETTEL, M., Heinemann, F., Engelen, A., Neubauer, S. (20I I). Cross-functional integration of R\&D, Marketing and Manufacturing in radical and incremental product innovations and its effects on project effectiveness and efficiency. The Journal of Product Innovation Management, 28 (2), 25I-269.

BRYMAN, A. (2006). Integrating quantitative and qualitative research: how is it done? Qualitative Research, 6 (I), 97 II3.

BURGELMAN, R. A., Mandique, M.A, Wheelwright, S.C. (200I). Strategic Management of Technology and Innovation. $3^{a}$ ed. Singapure: McGraw-Hill Book.

BUSS, C. O. Cooperação interfuncional no desenvolvimento de novos produtos: a interface marketing-engenharia. Porto Alegre. 188p. Dissertação (Mestrado em Administração) Universidade Federal do Rio Grande do Sul, 2002.

CALANTONE, R., Rubera, G. (20I2). When should RD\&E and marketing collaborate? the moderating role of exploration-exploitation and environmental uncertainty, Journal of Product Innovation Management, 29 (I), I44-I57.

CERRA, A. L., Maia, J. L., Alves Filho, A.G. (20I0). Estratégias Tecnológicas de montadoras dos setores automobilístico e de linha branca uma análise comparativa por meio de estudos de caso. Revista de Administração, 45 (3), 27I-284.

CREVELING, C. M., Slutsky, J.L., Antis, D. (2003). Design for six sigma: in technology \& product development. New Jersey: Pretince Hall.

DREJER, A. (2002). Integrating product and technology development. International Journal Technology Management, 24, (2/3), I24- I 42.

EVANS, G., Gausselin, P. (2005). Technology management. In: Kahn, K. B. (ed.) The PDMA Handbook of new product development. $2^{\circ}$ ed, New Jersey: John Wiley \& Sons, 319-334.
EPPRINGER, S. D., CHITKARA, A.R. (2009). The practice of global product development. MIT Sloan Management Review, 2 I, I-II.

FARJOUM, M. (2010) Beyond dualism: stability and change as a duality,Academy of Management Review, 35 (2), 202-225.

GOPALAKRISHNAN, S., Santoro, M.D. (2004). Distinguishing Between Knowledge Transfer and Technology Transfer Activities: The Role of Key Organizational Factors, IEEE transactions on Engineering Management, 5 I (I), 57-69.

GREEN, S. G.,Welsh, M.A., Dehler, G.E. (1996). Transferring technology into R\&D: a comparison of acquired and inhouse product development projects, Journal of Engineering and Technology Management, I3( 2), I25-I 44.

GRIFFIN, A., Hauser, J. R. (1996). Integrating R\&D and marketing: a review and analysis of the literature. Journal of Product Innovation Management. I3 (3), I9I-2I5.

IANSITI, M. (1998). Technology integration: making critical choices in a dynamic world. Boston: HBS Press.

JOHANSSON, G., Magnusson, T., Säfsten, K., Lakemond, N. (2006). Case studies on the application industrial innovation process. In: Second European Conference on Management of Technology, Euromot, Birmingham, United Kingdom.

JUGEND, D., Silva, S. L. (20I2). Integration in new product development: case study in a large Brazilian high-technology company, Journal of Technology Management \& Innovation, 7(I), pp. 52-63.

JUGEND, D., Silva, S. L. (2010). Práticas de gestão que influenciam o sucesso de novos produtos em empresas de base tecnológica, Revista Produção, 20 (3), 335-346.

LEENDERS, M. A. A. M., Wierenga, B. (2002). The effectiveness of different mechanisms for integrating marketing and R\&D', The Journal of Product Innovation Management, 19 (2), 305-317.

LOVE, J. H., Roper, S. (2009). Organization innovation: complementarities between cross-functional teams. Technovation, 29(3), 192 -203.

MAGNUSSON, T., Johansson, G. (2008). Managing internal technology transfer in complex product development, European Journal of Innovation Management, I I (3),.349-365.

MALTZ, E., Souder,W.E., Kumar,A.A. (200I). Influencing R\&D/ marketing integration and the use of market information by R\&D managers intended and unintended effects of managerial actions. Journal of Business Research, 52, (I), 69-82.

ISSN: 07 I8-2724. (http://www.jotmi.org) 
NOBELIUS, D. (2004). Linking product development to applied research: transfer experiences from an automotive company.Technovation, 24 (4), 2004.

OLIVEIRA, M. G., Freitas, J.S., Fleury, A. L., Rozenfeld, H., Phaal, R., Probert, D., Cheng, L. C. (20I2). Roadmapping: uma abordagem estratégica para o gerenciamento da inovação em produtos, serviços e tecnologias, Rio de Janeiro: Elsevier, 2012.

OLSON, E. M., Orville, C.W., Ruekert, R.W., Bonner, J.B. (200I). Patterns of cooperation during new product development among marketing, operations and R\&D: implications for project performance. Journal of Product Innovation Management, I8 (4), 258-27I.

PARK, M. H., Lim, J.W., Birnbaum-More, P. H. (2009). The effect of multiknowledge individuals on performance in crossfunctional new product development teams. The Journal of Product Innovation Management, 26(I), 89 -96.

PHAAL, R., Clare, J. P., Probert, D.R. (2004). A framework for supporting the management of technological knowledge, International Journal of Technology Management, 27 (I), I-I5.

PRIEST, J.W., Sanchez, J. M. (200I). Product development and design for manufacturing: a collaborative approach to producibility and reliability. New York, NY: Marcel Dekker, Inc.

SHULZ, A. P., Clausing, D., Fricke, E., Negele, H. (2000). Development and integration of winning technologies as key to competitive advantage. Systems Engineering, 3 (4), I80- 2 I I.

SONG, L. Z., Song, M. (2010). The role of information technologies in enhancing R\&D-Marketing integration: an empirical investigation, Journal of Product Innovation Management, 27(3), 382-40I.

SONG, X. M., Xie, J., Dyer, B. (2000).Antecedents and consequences of marketing manager's conflict handling behaviors, Journal of Marketing, 64 (I), 50-66.

SOUDER,W.E., Buisson, D., Garret,T.(1997). Success through customer-driven new product development: a comparison of US and New Zealand small entrepreneurial high technology firms. Journal of Product Innovation Management, I4 (6), 459-472.

WHITNEY, D. E. (2007) Assemble a technology development tollkit. Research Technology Management, 50 (5),. 52-58.

YIN, R. K. (2005). Estudo de caso: planejamentos e métodos. $3^{\mathrm{a}}$ ed., Porto Alegre: Bookman. 